\title{
Ecology and Evolution of Soil Nematode Chemotaxis
}

\author{
Sergio Rasmann • Jared Gregory Ali • \\ Johannes Helder • Wim H. van der Putten
}

Received: 6 February 2012 /Revised: 30 March 2012 /Accepted: 6 April 2012 /Published online: 25 April 2012

(C) Springer Science+Business Media, LLC 2012

\begin{abstract}
Plants influence the behavior of and modify community composition of soil-dwelling organisms through the exudation of organic molecules. Given the chemical complexity of the soil matrix, soil-dwelling organisms have evolved the ability to detect and respond to these cues for successful foraging. A key question is how specific these responses are and how they may evolve. Here, we review and discuss the ecology and evolution of chemotaxis of soil nematodes. Soil nematodes are a group of diverse functional and taxonomic types, which may reveal a variety of responses. We predicted that nematodes of different feeding guilds use host-specific cues for chemotaxis. However, the examination of a comprehensive nematode phylogeny revealed that distantly related nematodes, and nematodes from different feeding guilds, can exploit the same signals for positive orientation. Carbon dioxide $\left(\mathrm{CO}_{2}\right)$, which is
\end{abstract}

\footnotetext{
S. Rasmann $(\bowtie)$

Department of Ecology and Evolution, UNIL Sorge, Le Biophore,

University of Lausanne,

1015 Lausanne, Switzerland

e-mail: sergio.rasmann@unil.ch

J. G. Ali

Department of Ecology and Evolutionary Biology,

Cornell University,

E145 Corson Hall,

Ithaca, NY, USA

J. Helder $\cdot$ W. H. van der Putten

Laboratory of Nematology, Wageningen University,

Droevendaalsesteeg 1,

6708 PB Wageningen, the Netherlands

W. H. van der Putten

Department of Terrestrial Ecology,

Netherlands Institute of Ecology NIOO-KNAW,

Droevendaalsesteeg 10 ,

6708 PB Wageningen, the Netherlands
}

ubiquitous in soil and indicates biological activity, is widely used as such a cue. The use of the same signals by a variety of species and species groups suggests that parts of the chemo-sensory machinery have remained highly conserved during the radiation of nematodes. However, besides $\mathrm{CO}_{2}$, many other chemical compounds, belonging to different chemical classes, have been shown to induce chemotaxis in nematodes. Plants surrounded by a complex nematode community, including beneficial entomopathogenic nematodes, plant-parasitic nematodes, as well as microbial feeders, are thus under diffuse selection for producing specific molecules in the rhizosphere that maximize their fitness. However, it is largely unknown how selection may operate and how belowground signaling may evolve. Given the paucity of data for certain groups of nematodes, future work is needed to better understand the evolutionary mechanisms of communication between plant roots and soil biota.

Keywords Carbon dioxide - Caenorhabditis elegans . Chemotaxis - Entomopathogenic nematodes - Functional phylogenetic $\cdot$ Nematode $\cdot$ Plant-parasitic nematodes $\cdot$ Sense organs $\cdot$ Soil chemical ecology

\section{Introduction}

All animals depend on green plants, either directly or indirectly, as their primary source of energy. Primary consumers need plants for nourishment, whereas secondary consumers, such as predators or parasites may use plant cues to locate their herbivore hosts. Several decades of work have shown that animals use plant-derived physical (visual, tactile), and/ or chemical (olfactory, gustatory) cues to locate and accept their food source (Schoonhoven et al., 2005). Most of these multitrophic interactions studies have been done using 
aboveground communities (Price et al., 1980; Vet and Dicke, 1992; Tscharntke and Hawkins, 2002). However, the last decade has shown a marked increase in exploring interactions between plants and soil animals (e.g., Strong et al., 1999; Gange and Brown, 2002; De Deyn et al., 2003; Van der Putten, 2003; de la Peña et al., 2006; Rasmann and Agrawal, 2008; Bonkowski et al., 2009), and how plants mediate interactions between aboveground and belowground communities (Van der Putten et al., 2001; Wardle, 2002; Bezemer and van Dam, 2005; Erb et al., 2008; Kaplan et al., 2008; van Dam, 2009). Indeed, roots often are the storage site for nutrients and metabolites, are a place where energy from photosynthesis can be stored, and can act as a shelter for soil-dwelling organisms (Hunter, 2001). Therefore, roots are a hub for ecological interactions that ultimately influence almost all groups of soil inhabitants (Coleman, 1976; Fogel, 1985; Walker et al., 2003; Whittaker, 2003).

General patterns and theories for chemically-mediated interactions that structure aboveground communities (Price et al., 1980; Vet and Dicke, 1992; Karban and Baldwin, 1997) also can be applied belowground (Strong et al., 1999; van Tol et al., 2001; van der Putten et al., 2009; Rasmann et al., 2011a). In fact, as aboveground, plants can influence the behavior, abundance, and composition of soil animal communities (e.g., Yeates, 1999; Buyer et al., 2002; Viketoft et al., 2009), and can mediate indirect interactions between organisms of different trophic levels (Coleman, 1976; Strong et al., 1999). However, striking differences exist between above- and belowground subsystems (see also Erb et al., 2012, this issue).

The soil matrix is composed of all three phases (gas, liquid, and solid), which can impact mobility, behavior, signaling, and interaction between organisms in a different manner than when living aboveground. This will influence the mobility of organisms belowground, often not surpassing more than $1 \mathrm{~m}^{2}$ in their lifetime, whereas aboveground, vertebrates can explore more than 1 ha per day (Hedlund et al., 2004). Moreover, the physico-chemical legacy of the soil, shaped by high metabolic retention capacity, slow turnover of chemical metabolites, slower diffusion, and higher heterogeneity suggests a slower rate for ecological interactions to occur (Coleman et al., 2004). Roots themselves also have a very different physiology, which may lead to distinct patterns of interactions belowground compared to aboveground (see Erb et al., 2012, this issue). All this together should impose selection for particular stimuli to be perceived by soil organisms. For example, soil inhabitants are strongly limited in their use of visual information, but rather use chemical and tactile cues to communicate and behave (Jones, 2002). Roots can produce and exude into the rhizosphere a great variety of compounds ranging from amino acids, complex polysaccharides, and proteins, to smaller, more volatile lipophilic molecules, all of which also have been shown to directly or indirectly influence the soil community of organisms (Bais et al., 2006). The aim of our review is to list and discuss published information on how plant chemical exudates can influence the ecology and evolution of host-searching and foraging strategies of soil-borne nematodes (but see also Johnson and Nielsen (2012), this issue for discussion on belowground herbivorous insects).

We particularly focus on soil nematodes because they are among the most diverse groups of soil organisms. Each square meter of soil may contain millions of individual nematodes belonging to over 400 species (Gaugler and Bilgrami, 2004). There are at least seven functional types, including: plant feeding nematodes (e.g., the genera Pratylenchus, Heterodera, Meloidogyne, Helicotylenchus, Aphelenchoides), plant-associated nematodes (e.g., the genera Tylenchus, Dorylaimellus), fungal hyphae-feeding nematodes (e.g., the genera Aphelenchus, Aphelenchoides, Leptonchus, Diphtherophora), bacterial feeding nematodes (e.g., the genera Rhabditis, Plectus, Cephalobus, Caenorhabditis), nematodes that feed on unicellular eukaryotes, animal-parasitic nematodes (e.g., the genera Heterorhabditis, Steinernema), and omnivorous nematodes (e.g., the order Dorylaimida) (Yeates, 1999). These functional types are taxonomically heterogeneous, and most likely the result of convergent evolution (e.g., Blaxter et al., 1998; Holterman et al., 2006). Additionally, it is worth noting that more than one feeding habit can occur within a genus (e.g., the genus Aphelenchoides harbors fungivorous and plant-parasitic species), or even within a single individual (Yeates, 1999).

Because of their abundance, systematic and functional diversity, and their representation in multiple trophic levels in the soil food web, nematodes have strong influences on ecosystem dynamics and functioning (Yeates et al., 2009). They have been shown to influence soil nutrient cycling, growth rate, health, and yield of plants as well as populations of other soil inhabitants. For example, herbivores influence plant yield (Chitwood, 2002), plant community composition (De Deyn et al., 2004), and successional dynamics (Mortimer et al., 1999; De Deyn et al., 2003). Microbial feeders can stimulate nutrient cycling and plant yield (Ingham et al., 1985; Fu et al., 2005). Detritivorous nematodes can contribute up to $40 \%$ of total organic matter mineralization (De Ruiter et al., 1993), and predators and parasites can reduce arthropod populations (e.g., Kaya and Gaugler, 1993), which in turn can have cascading effects on plant performance (Strong et al., 1999; Rasmann et al., 2011b).

Below, we review literature of nematode sensory machinery and chemically-mediated orientation toward organic molecules. Little is known of how chemotaxis has evolved during the radiation of nematodes. Chemotaxis is the directed orientation of the nematode toward or away from the source of stimulation (in our case the plants). Using a 
comprehensive phylogeny of nematodes, we map chemical compounds that have been proven to produce taxis. This will lead to preliminary conclusions on how chemotaxis can evolve in soil nematodes. Finally, we discuss how plants can structure communities of nematodes through root exudation and how this may operate to their own benefit.

\section{The Sensory Apparatus of Soil Nematodes}

As in all animals, nematode behavior is the coordinate integration of several external stimuli leading to responses (e.g., locomotion, movement, feeding, mating, penetration) (Gaugler and Bilgrami, 2004). Nematodes' sensory apparatus allows them to use chemical, electrical, light, mechanical, and temperature stimuli (Jones, 2002) to orientate, move, and locate a sexual partner, as well as energy sources (food) in the soil (Lee, 2002).

Nematode sense organs basically can be subdivided into cuticular and internal sense organs. Cuticular sense organs generally are composed of a sheath cell, a socket cell, and a variable number of dendritic processes, and are responsible for detecting chemical, mechanical and temperature related stimuli. Internal sense organs are more diverse, mainly responsible for detecting mechanical stimuli as well as light stimuli (Jones, 2002). Invariably, the largest and most complex of the nematode sense organs are the amphids, which are exposed to the external environment by a pore in the cuticule, primarily functioning as chemoreceptors. In Caenorhabditis elegans, the tail bilateral sensory organs called phasmids also are shown to function as chemoreceptors and help the nematode orientate towards or away from the chemical stimuli (Hilliard et al., 2002). Numerous nematode taxa do not have phasmids (e.g., members of Clade 1-6 according to Holterman et al. (2006)). Because of the complexity and abundance of soil chemicals compared to other physical stimuli, chemoreception is undoubtedly the most important source of stimulus to nematodes (Jones, 2002).

Responses by nematodes to chemical stimuli have been extensively studied in the bacteriophagous nematode $C$. elegans, some plant-parasitic (e.g., Meloidogyne and Globodera spp.), and in an increasing number of animal-parasitic nematodes (e.g., Heterorhabditis and Steinernema spp.). Among the genera mentioned above, $C$. elegans has an uncommon ecology: it is present only in nutritionally very rich habitats (e.g., mature compost heaps), and is seldom found in 'normal' soils. Hence, some restraint in the extrapolation of C. elegans data to other genera would be justified.

\section{Chemotaxis in Nematodes}

In sections below and in Table 1, we summarize major chemo-attractants for soil nematodes. The high occurrences of a wide variety of compounds known to mediate changes in nematode behavior for particular species (e.g., C. elegans) are likely due to research bias towards model species. For example, because of the ability to map gene-level responses with behavior, studies of attraction/repulsion to/ from allelochemicals in C. elegans comprise most of the work done on all nematodes (Bargmann and Mori, 1997). Although some compounds have been identified as potent nematode repellents, such as, D-tryptophan, $\alpha$-terthienyl, high levels of $\mathrm{CO}_{2}$, copper and zinc ions, and inositol (Balanova and Balan, 1991; Ward, 1978), we focused on plant produced kairomones, which stimulate positive orientation, and also because most studies assess positive orientation in nematode bioassays. This will set the stage for discussing evolutionary ecology of plant-nematode interactions.

Chemotaxis of Plant-Parasitic Nematodes Plant-parasitic nematodes can be divided into broad groups based on the plant parts they infest. Foliar nematodes (Aphelenchoides sp.) move into shoots and invade leaf buds causing necrosis and deformation of plant leaves. The stem nematodes (Ditylenchus dipsaci) cause malformations, decline in growth, and dry rot in above- and belowground parts of stems. Other nematodes infect roots and cause growth reduction in whole plants and malformations in underground plant parts (Meloidogyne spp., Rotylenchus uniformis), root necrosis, and growth reduction (Pratylenchus penetrans, Tylenchulus semipenetrans), or growth reduction without any obvious or typical symptoms (Globodera rostochiensis, G. pallida, and Tylenchorhynchus dubius). Here, we limit our analysis of allelochemicals that affect soil-dwelling plant-parasitic nematodes, which mainly exploit plant roots as their only source of nutrients. Species of plant-parasitic nematodes may spend their whole life cycle outside the plant, feeding from the surface or deeper tissues, while others have the capacity to invade the root and feed from cortical cells. In many cases, feeding cells are transformed into highly specialized feeding structures to support nematode development and reproduction such as for cyst (e.g., Heterodera and Globodera spp.) and root-knot nematodes (Meloidogyne spp.) (Wyss, 2002). Both these so-called sedentary endoparasites are economically important because of their ability to cause damage to major crop species.

Different control mechanisms underlie the hatching of cyst and root knot nematodes. Root knot nematodes in general have a far broader host range than cyst nematodes. Because of their specificity, it is essential for cyst nematodes to hatch in the direct vicinity of a suitable host plant, instead of near any plant species. Cyst nematode hatching is triggered by a complex mixture of components released by the roots of host plants in a species-dependent manner (Prot, 1980). There is a variable degree of dependence of cyst 
Table 1 Attractive chemical compounds for different trophic guilds of soil nematodes. Shown are nematodes species grouped in three different guilds (bacteriophagous, entomopathogenic, and plant-parasitic) and their corresponding chemical attractant. Choice of the references is based on whether the study correlated actual nematode behavior with individual chemical compounds present. We excluded all compounds that stimulated repulsion, but we acknowledge that different concentrations of the same compounds can be either attractive or repulsive (see text). Note that entomopathogenic nematodes are functionally bacteriophagous, but cannot grow and reproduce outside the arthropod protective shell, making them unique in regard of their guild

Feeding guilds and nematode species Attractive compound

Bacterivorous

Caenorhabditis elegans

Entomopathogen

Heterorhabditis bacteriophora

2,3 butanedione
2-butanone
2-pentanone
3-carene
4,5 dimethylthiazole
$\alpha$-humulene
$\alpha$-pinene
benzothiazole
cAMP
carbon dioxide
ethylacetate
ions
linalool
methyl acetate
octadecanoid acid
propanol
trimethylamine

(E)- $\beta$-caryophyllene 1-heptanol

1-hexanol

1-nonanol

1-octanol

1-pentanol

2-acetylthiazole

2-heptanol

2-isobutylthiazole

2-methylpyrazine

2-nonanol

2-octanol

3-nonanol

4,5 dimethylthiazole

4,5-dimethylthiazole

benzothiazole

caproic acid

caprylic acid

carbon dioxide

methy salicilate

methylvaleric acid

p-cymene

propanol

undecyl acetate

H. indica geijerene

pregeijerene ketone

terpenes

thiazoles

terpenes

thiazoles

cAMP

atmospheric gaz

acids

ions

terpenes

acids

alchools

amines

terpenes

alcohols

thiazoles

alcohols

thiazoles

pyrazines

alcohols

thiazoles

thiazoles

thiazoles

acids

atmospheric gaz

aromatic compound

acids

terpenes

alcohols

acids

terpenes
References

(Hallem et al., 2011)

(Hallem et al., 2011)

(Hallem et al., 2011)

(Hallem et al., 2011)

(Hallem et al., 2011)

(Hallem et al., 2011)

(Hallem et al., 2011)

(Hallem et al., 2011)

(Bird, 1960)

(Bird, 1960)

(Hallem et al., 2011)

(Ward, 1978)

(Hallem et al., 2011)

(Hallem et al., 2011)

(Hallem et al., 2011)

(Hallem et al., 2011)

(Hallem et al., 2011)

(Rasmann et al., 2005)

(O'Halloran and Burnell, 2003)

(O’Halloran and Burnell, 2003)

(O'Halloran and Burnell, 2003)

(O'Halloran and Burnell, 2003)

(O’Halloran and Burnell, 2003)

(O'Halloran and Burnell, 2003)

(O'Halloran and Burnell, 2003)

(O'Halloran and Burnell, 2003)

(O'Halloran and Burnell, 2003)

(O'Halloran and Burnell, 2003)

(O'Halloran and Burnell, 2003)

(O’Halloran and Burnell, 2003)

(Hallem et al., 2011)

(O’Halloran and Burnell, 2003)

(O'Halloran and Burnell, 2003)

(O’Halloran and Burnell, 2003)

(O'Halloran and Burnell, 2003)

(O'Halloran and Burnell, 2003)

(Hallem et al., 2011)

(O'Halloran and Burnell, 2003)

(Hallem et al., 2011)

(Hallem et al., 2011)

(Hallem et al., 2011)

(Ali et al., 2011)

(Ali et al., 2011) 
Table 1 (continued)

\begin{tabular}{|c|c|c|c|}
\hline Feeding guilds and nematode species & Attractive compounds & Compounds' type & References \\
\hline \multirow[t]{2}{*}{ H. megidis } & $(E)-\beta$-farnesene & & (Kollner et al., 2008) \\
\hline & (E)-nerolidol & & (Kollner et al., 2008) \\
\hline \multirow[t]{9}{*}{ Steinernema carpocapsae } & 2-nonanone & ketone & (Hallem et al., 2011) \\
\hline & 4,5 dimethylthiazole & thiazoles & (Hallem et al., 2011) \\
\hline & carbon dioxide & gaz & Gaugler et al. 1980 \\
\hline & heptanol & alcohol & (Hallem et al., 2011) \\
\hline & hexanol & & (Hallem et al., 2011) \\
\hline & nonanol & & (Hallem et al., 2011) \\
\hline & octanol & & (Hallem et al., 2011) \\
\hline & octyl acetate & acids & (Hallem et al., 2011) \\
\hline & pentanol & alcohols & (Hallem et al., 2011) \\
\hline S. diaprepsi & $\alpha$-santalene & terpenes & (Ali et al., 2011) \\
\hline S. feltiae & $\alpha$-santalene & & (Ali et al., 2011) \\
\hline S. glaseri & carbon dioxide & gaz & (Robinson, 1995) \\
\hline S. riobrave & $\alpha$-santalene & terpenes & (Ali et al., 2011) \\
\hline \multicolumn{4}{|l|}{ Plant-parasite } \\
\hline Aphelenchoides fragariae & carbon dioxide & gaz & (Bird, 1960) \\
\hline A. ritzemabosi & carbon dioxide & & (Klinger, 1970) \\
\hline Ditylenchus dipsaci & carbon dioxide & & (Pline and Dusenbery, 1987) \\
\hline \multirow[t]{2}{*}{ Globodera pallida } & g-aminobutyric acid & acids & (Riga, 2004) \\
\hline & L-glutamic acid & & (Riga, 2004) \\
\hline \multirow[t]{2}{*}{ G. rostochiensis } & a-aminobutiric acid & & (Riga, 2004) \\
\hline & L-glutamic acid & & (Riga, 2004) \\
\hline Heterodera schactii & carbon dioxide & gaz & (Bird, 1960) \\
\hline Meloidogyne incognita & carbon dioxide & & (McCallum and Dusenbery, 1992) \\
\hline M. javanica & carbon dioxide & & (Pline and Dusenbery, 1987) \\
\hline Panagrellus silusiae & carbon dioxide & & (Viglierchio, 1990) \\
\hline \multirow[t]{2}{*}{ Rotylenchus reniformis } & cAMP & cAMP & (Riddle and Bird, 1985) \\
\hline & ions & ions & (Riddle and Bird, 1985) \\
\hline \multirow[t]{4}{*}{ Tylenchulus semipenetrans } & geijerene & terpenes & (Ali et al., 2011) \\
\hline & ions & ions & (Abou-Setta and Duncan, 1998) \\
\hline & limonene & terpenes & (Ali et al., 2011) \\
\hline & pregeijerene & & (Ali et al., 2011) \\
\hline
\end{tabular}

nematodes on these plant cues: whereas exposure to root diffusates is almost a prerequisite for the hatching of potato cyst nematodes (Globodera rostochiensis and G. pallida), the hatching of soybean and beet cyst nematodes (Heterodera glycines and $H$. schachtii) is merely stimulated by such compounds. In contrast, the hatching of root knot nematodes is mainly temperature driven (Perry and Wesemael, 2008).

One of the remarkable characteristics of root diffusatebased hatching of cyst nematodes is the high activity of host plant-derived hatching stimuli ("eclepins"). The water-soluble glycinoeclepins A, B, and C (pentanor- (A) or nortriterpenes (B and $\mathrm{C})$ ) isolated from the roots of kidney bean are active at concentrations as low as $10^{-11}-10^{-12} \mathrm{~g}$ per ml (Masamune et al., 1982). The tetranortriterpene solanoeclepin A released by the roots of potato are active in the same concentration range (Schenk et al., 1999). Interestingly, glycino and solanoeclepins are chemically closely related triterpenes.

Diffusion in the liquid phase is the main mechanism responsible for spreading eclepins in soil, and eclepindependent cyst nematode species will hatch only in the close vicinity of a host root ( $\mathrm{cm}$ range). It is conceivable that the freshly hatched pre-parasitic juveniles can follow relatively unspecific cues, such as $\mathrm{CO}_{2}$ to reach the root of a host plant. Such a general signaling compound would not work for root knot nematodes, as their hatching is mainly triggered by a very general signal (viz. soil temperature). However, root knot nematodes are highly polyphagous. This applies especially to the most abundant species in 
agro-ecosystems, such as M. incognita, M. javanica, and $M$. arenaria. For these nematodes, following a steep (plantderived) $\mathrm{CO}_{2}$ gradient would imply a reasonable chance to reach a suitable plant root. The attraction of $M$. incognita by $\mathrm{CO}_{2}$ has been shown in several studies (Dusenbery, 1987; Pline and Dusenbery, 1987). A related, alternative mechanism for host finding by root knot nematodes was proposed by Wang et al. (2009). Juveniles of Meloidogyne hapla had a strong preference for $\mathrm{pH}$ between 4.5 and 5.4, and the authors proposed root knot nematodes to be attracted by dissolved $\mathrm{CO}_{2}$, resulting in local acidification, rather than by $\mathrm{CO}_{2}$ itself.

For plant-parasitic nematodes other than cyst or polyphagous root knot nematodes, it is critical to exploit chemical gradients in soil that relate to the presence of a suitable host plant. For these nematodes, olfactory and other sensory organs of the nematode are essential (Huang et al., 2003). It has been acknowledged for long that plant-parasitic nematodes can locate roots of host plants in the soil (Prot, 1980) by using allelochemicals produced by the plants, as well as other soil-borne chemical compounds (Perry and Aumann, 1998). However, besides the general signal furnished by carbon dioxide $\left(\mathrm{CO}_{2}\right)$ emissions, the factors that trigger plant-parasitic nematode attraction and direction are still largely unexplored (Table 1). Carbon dioxide was shown to attract Ditylenchus dipsaci (Klinger, 1963; Dusenbery, 1980). Increased $\mathrm{CO}_{2}$ levels in Fusarium oxysporum infested lucerne (Medicago sativa) roots, attracted P. penetrans to infected roots (Edmunds and Mai, 1967). Other, non-identified diffusates from the roots of potato increased the activity and also attracted the infective second stage juveniles of the potato cyst nematode (G. rostochiensis) to the roots (Perry, 1997; Devine and Jones, 2003). Similarly, M. javanica and G. rostochiensis juveniles may respond to tomato (Prot, 1980) and potato (Rolfe et al., 2000) root diffusates, respectively (reviewed in Curtis et al., 2009). The use of these attractive plant properties has been a proposed method for luring nematode pests to non-host trap crops (Franco et al., 1999). Exudates from Asparagus officinalis and Tagetes erecta are attractive to a wide range of nematodes, however, once lured in they are killed by the plants' defensive compounds (glycosides and thiophene from A. officinalis and T. erecta, respectively) (Bilgrami, 1997). Although the orientation of endoparasitic nematodes to preferred invasion sites is well established, the exact compounds in the diffusate responsible for attraction are not known (Curtis et al., 2009).

Besides $\mathrm{CO}_{2}$, other volatile organic molecules have also been shown to serve as attractants (Table 1) or repellents for plant-parasitic nematodes, such as M. incognita, (McCallum and Dusenbery, 1992). Castro et al. (1989) demonstrated that volatiles from cucumber roots were attractive to $M$. incognita. Only very recently, however, it was shown that plant-parasitic nematodes can follow gradients of herbivoreinduced terpenoid volatile organic compounds; Tylenchulus semipenetrans were more attracted to Citrus spp. roots infested by weevil larvae compared to uninfested plants (Ali et al., 2010, 2011). A series of terpene compounds were identified, including $\alpha$-pinene, $\beta$-pinene, limonene, geijerene, and pregeijerene (Ali et al., 2011).

Chemical Ecology of Entomopathogenic Nematodes Soildwelling entomopathogenic nematodes comprise two families: Steinernematidae (genus Steinernema and Neosteinernema) and Heterorhabditidae (genus Heterorhabditis). They only grow and reproduce inside arthropod hosts, and third instar infective juveniles leave the cadaver. The infective juvenile (dauer juvenile) is the only stage that can survive without food for long periods while searching for alternative hosts in the soil (Gaugler, 2002). All members of both these families are actually bacteriophagous, having evolved the ability to carry and introduce symbiotic bacteria into the body cavities of insects. Bacteria then reproduce in the insect, thus furnishing the food for the nematodes to complete their life-cycle (Poinar, 1990). Because of their ability to kill the majority of insect orders and families in the soil, and the relative ease of large-scale culturing in artificial solid or liquid media, they have been promoted as exceptionally good candidates for the biological control of insect pests of roots in crop fields (Gaugler and Kaya, 1990). In general, foraging strategies of entomopathogenic nematodes can be divided into two broad categories; a cruiser form, which is highly mobile, and an ambusher form (sit-and-wait) (Campbell and Gaugler, 1997). Cruising foragers have a higher probability of finding sedentary and cryptic resources than ambushers, and ambush foragers are more effective at encountering resources with high mobility (Lewis, 2002). However, direct evidence suggests that foraging strategies used by different infective juveniles species to find a host vary along a continuum between ambush and cruise foragers (Campbell and Gaugler, 1993; Campbell and Gaugler, 1997; Lewis et al., 1992, 1993), and this behavior is plastic depending on the habitat type (Ennis et al., 2010).

Entomopathogenic nematode attraction to a suitable host can integrate different possible cues such as temperature, electric potential, carbon dioxide, and various organic and inorganic substances. However, no specific compound has been put forward for entomopathogenic nematode attraction toward the insect host (Kaya and Gaugler, 1993; Boff et al., 2001). It is generally assumed that nematode orientation and aggregation is due to unspecific signaling, such as $\mathrm{CO}_{2}$ emissions. For example, Lewis et al. (1993) found that $S$. glaseri responded positively to volatiles cues from an insect host, and that this response was eliminated if $\mathrm{CO}_{2}$ were removed. A similar response was later found by Grewal et al. (1994) for other cruiser Steinernema spp. and for two species of Heterorhabditis. This general response to 
unspecified volatile cues has been extended to many other Steinernema spp. (Campbell et al., 2003). On the other hand, it has been argued that $\mathrm{CO}_{2}$ should function mainly as a short-range attractant, playing a role in host penetration through the spiracles (Ishibashi and Kondo, 1990). It also seems unlikely that such a general signal could be unambiguously exploited by foraging nematodes looking for a specific arthropod host feeding on roots. Indeed, Bilgrami et al. (2001b) found that $S$. glaseri was attracted to plant tissue from roots and leaves from $A$. officinalis and T. erecta, but not to nitrogenous insect products (Bilgrami et al., 2001a). Moreover, it was proposed simultaneously that entomopathogenic nematodes can use arthropod herbivore-induced plant cues to locate the site of wounding, which would automatically reveal the host (Boff et al., 2001, 2002; van Tol et al., 2001).

To date, few tritrophic interactions implying belowground herbivore-induced volatile compounds have been described, but examples include both agricultural (Rasmann et al., 2005; Ali et al., 2010, 2011) and (semi-) natural systems (Rasmann et al., 2011b). Nematodes $H$. megidis, and $H$. bacteriophora have been shown to be attracted to the sesquiterpene $(E)-\beta$-caryophyllene emitted by insect-damaged corn (Zea mays) plants (Rasmann et al., 2005; Rasmann and Turlings, 2008). Ali et al. (2010) demonstrated that citrus roots upon feeding by the root weevil Diaprepes abbreviates emit several terpenes including $\alpha$ pinene, $\beta$-pinene, limonene, geijerene, and pregeijerene, which attracted S. carpocapsae, S. diaprepesi, S. riobrave, and $H$. indica from the surrounding soil. Further studies demonstrated that application of isolated HIPV pregeijerene increased larval mortality in citrus and blueberry agroecosystems by attracting naturally occuring EPN species (Ali et al. 2012 In press). Recently, Hallem et al. (2011) reported positive chemotaxis of $H$. bacteriophora and $S$. carpocapsae nematodes to several volatiles such as methyl salicylate, hexanol, heptanol, undecyl acetate, or 4,5-dimethylthiazole. Interestingly, they also showed that several volatiles repelled the same nematodes.

Chemotaxis and C. elegans In the bacteriophagous $C$. elegans, attraction can be mediated by a wide variety of compounds, including anions, cations, amino acids, nucleotides, variation in $\mathrm{pH}$, vitamins, bacteria derived cyclic AMP, or various volatile organic compounds including the wellstudied $\mathrm{CO}_{2}$ (reviewed in Lee, 2002). Single chemosensory neurons are able to detect high and low concentrations of a single odorous compound (Sengupta et al., 1993). Also, odorant responses can adapt to various concentrations, which is reversible (Sengupta et al., 1993). Generally, responses to chemicals are dependent on developmental stage or, likely, other unknown environmental factors (Goode and Dusenbery, 1985; Riddle and Bird, 1985).
Chemotaxis and Other Nematodes Based on current systematic, ecological, and physiological knowledge, only a small fraction of nematodes are parasites of plants or animals. In fact, most nematode diversity is represented by species that are free-living in fresh water, marine, or soil systems (Baldwin et al., 2004). Free-living nematodes forage on a wide variety of substrates including bacteria, fungi, or plants. Little is known of the exact allomones that drive behavior and attraction of all other nematodes. It has been shown that secretions from fungal mycelia can attract the fungal feeder Paurodontoides linfordi (Klink, 1969). The free-living nematode Panagrellus redivivus was strongly attracted to cell-free filtrates of culture media of certain yeast and fungi, suggesting that material released by the microorganisms, such as esters or fatty acids serve as chemo-attractants (Balanova and Balan, 1991). Similarly, the free-living nematodes Acrobeloides sp. and Pristionchus lheritieri are attracted to kairomones emitted by suitable bacterial food in culture (Anderson and Coleman, 1981).

\section{Ecology and Evolution of Soil Nematode Chemotaxis}

In the complex soil matrix, in which gaseous, liquid, and solid phases can co-exists, nematodes have been shown to rely on both volatile, as well as water-soluble molecules for foraging (Bargmann and Horvitz, 1991). Indeed, it has been argued that $C$. elegans nematodes can rely on both watersoluble molecules (i.e., taste) and volatile molecules (i.e., smell) for different chemotaxis behaviors. Bargmann and Mori (1997) suggested that as volatile molecules travel quickly through diffusion and turbulence in the air, they may be used for longer-range chemotaxis, whereas watersoluble molecules are mainly used for short-range chemotaxis . For example, H. megidis nematodes, attracted to the corn-produced sesquiterpene $(E)$ - $\beta$-caryophyllene, have been recollected at $0.5 \mathrm{~m}$ distance from the release point after 2 weeks (Rasmann et al., 2005, 2011b). Proportionally, to equate a nematode, humans would need to travel at $1,500 \mathrm{~km} \mathrm{~h}^{-1}$ to cover the same distance!

Evidence gathered in this review would suggest that both short- and long-range chemotaxis are widespread among different nematode taxa. Nematodes from different feeding guilds and from different branches of the phylogeny, indeed, utilize various, often similar, volatile, and non-volatile compounds in the soil to locate their food sources (Table 1). Undoubtedly, nematodes have evolved to sense compounds originating from a relatively long distance. However, the question is if the trait for smelling particular and possibly specific compounds may have evolved independently several times during nematode radiation. Alternatively, all nematodes may be able to smell the same molecules. In that 
case, the "smell" trait may be general and may have been conserved during the radiation of nematodes.

We mapped the nematode phylogeny and chemical compounds that stimulate attraction in different nematodes feeding groups in combination (Fig. 1). Such mapping showed that: 1) different feeding guilds of nematodes have repeatedly and independently evolved several times during the radiation of the group (Baldwin et al., 2004; Bert et al., 2011). This implies convergent evolution of feeding habits among soil nematodes. 2) Although we acknowledge the paucity of data, preliminary results suggest that some compounds such as $\mathrm{CO}_{2}$ or some ions can be detected and used by a wide variety of different feeding guilds. This implies phylogenetic conservatism in chemical compound use. In other words, if traits responsible for recognition of particular compounds are conserved during the radiation of nematodes into different feeding guilds, we should then expect a broad distribution of similar compounds that can initiate a chemotaxis response, which is what we can see in Table 1, and Fig. 1.

Although respiratory emissions of $\mathrm{CO}_{2}$ remain the most widely studied mechanism for nematode and soil-dwelling arthropod attraction (Johnson and Nielsen, 2012, this issue), this might not be the most effective mean for root location (Johnson and Gregory, 2006). In particular, in mixed stands or for specialized plant parasites, $\mathrm{CO}_{2}$ cannot provide reliable information. Furthermore, orientation toward $\mathrm{CO}_{2}$ gradients by the European cockchafer, Melolontha melolontha, disappeared when other plant-derived signals were present (Reinecke et al., 2008).

Indeed, besides $\mathrm{CO}_{2}$, other recently discovered compounds involved in nematode attraction include plantproduced sesquiterpene molecules that can trigger attraction for phylogenetically and functionally different nematodes. Ali et al. (2011) showed that insect-induced citrus root chemicals (geijerene and pregeijerene) can attract the phytopathogenic nematode $T$. semipenetrans, as well as entomopathogenic nematodes $S$. carpocapsae, $S$. riobrave, and $H$. indica. Other compounds found to be triggering chemotaxis in various nematodes include various ions, salts, and amino-acids, again arguing for conserved chemo-sensory machinery across nematode species.

Given this striking conservatism in nematode sensory behavioral responses, can we still expect the evolution of the ability to sense particular chemical compounds in the soil? High levels of specificity would be strongly suggestive of such a relationship. For example, four closely related marine bacteriophagous nematodes have partially overlapping microhabitat preferences. These nematodes were found to have species-specific differences in their responses to three different strains of bacteria. This suggests that the least some level of food specialization may have occurred in conjunction with a specialized chemotaxis response (Moens et al., 1999).
Fig. 1 Evolution of chemotaxis in nematodes. Shown is the schematic SSU rDNA-based phylogenic relationship between nematodes belonging to Clades 9-12 (based on Holterman et al., 2006). Right table shows identity of chemical compounds that have been associated with nematode attraction toward odor sources. 1) atmospheric gas $\left.\left(\mathrm{CO}_{2}\right), 2\right)$ alcohols, 3) ketones, 4) organic acids, 5) terpenoids, 6) thiazoles/ pyrazidines, 7) cAMP, 8) esters, 9) ions, 10) amines, 11) amino acids, 12) aromatic compounds. See Table 1 for specific compounds. Overall, the figure shows the overwhelming presence of $\mathrm{CO}_{2}$ as nematode attractant across different nematode taxa and feeding guilds. It also shows the paucity of data for many groups of nematodes (see text for details)

Similar to other adaptive traits, different nematode chemical receptors may evolve if there is heritable variation in their production and effect, which in turn affects fitness. To our knowledge, measurement of genetic variation in nematode chemotaxis for specific compounds, and how this affects nematode fitness has not yet been attempted. We do, however, have evidence that different strains of nematodes can be recruited by different chemical compounds (Hiltpold et al., 2010; Moens et al., 1999). As various plant-parasitic nematode strains can differentially infect a given host plant, recognition and attraction might indeed be under selection (Perry et al., 2009). Hiltpold et al. (2010) have shown that only few cycles of selection are sufficient to increase H. bacteriophora attraction toward corn emitting $(E)-\beta$-caryophyllene. It is likely that strong directional selection of nematode attraction in corn fields will enhance the efficacy of entomopathogenic nematodes.

Still, there remains a gap in our interpretation of how insect-parasitic nematodes would have become sensitive to indirect cues of host location, such as herbivore induced plant volatiles. Answers may be provided when considering the life histories of closely related nematode taxa, along with their associated bacteria. For example, the insect-parasitic nematode genus Heterorhabditis most closely resembles a genus of marine nematodes, Pellioditis (Dougherty and Nigon, 1949). Species from Pellioditis are selective bacterial feeders that occur in intertidal and coastal regions (Poinar, 1993). There is evidence that the heterorhabditids evolved in a costal habitat from free-living microbiotrophic marine nematodes (Hara et al., 1991; Poinar, 1993). The bioluminescent bacterium that is responsible for the pathogenic effects of Heterorhabidtis on invertebrates is Photorhabdus. These bacteria are believed to have originated from a marine shore habitat, where there are many reports of living and dead marine invertebrates containing luminescent bacteria (Harvey, 1952). Pellioditis marina, a candidate for a pelloiditid that could have evolved into an insectparasitic heterorhabditid, can survive on a luminescent bacteria (Tietjen et al., 1970). This may reveal a scenario that could permit a free-living bacterial feeder like P. marina to have evolved into an insect-parasitic nematode, where an injective juvenile came in contact with and retained bacteria 


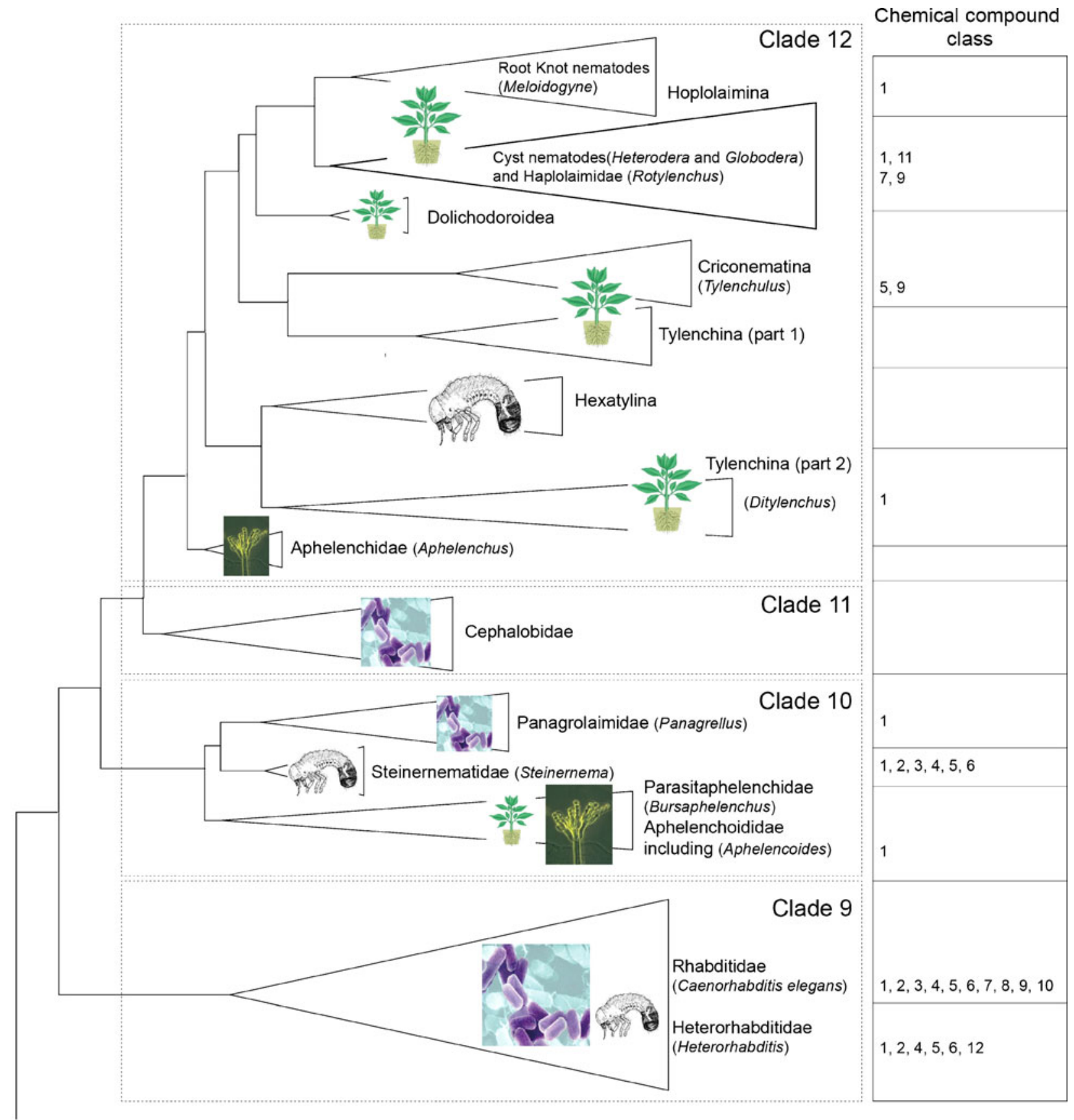

\section{Clades 1-8}

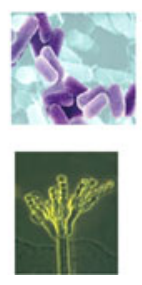

bacterivore

fungivore

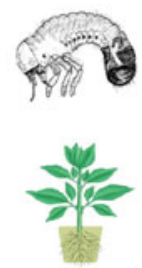

insect parasite

plant parasite

lethal to invertebrates. This early heterorhabditid need only to parasitize a littoral and beach dwelling crustacean, and a shift from crustacean to an insect would not have been difficult. Possible hosts would be root-feeding weevils (Otiorhynchus spp., Curculionidae) that are found along seacoasts on the roots of beach grasses (e.g., Ammophila 
arenaria or seashore wormwood, Artemisia maritima) or scarabid larvae of Aegialia arenaria (Scarabidae) along coastal dwelling and beach grass root feeders (Von Lengerken, 1929). Interestingly, scarabs and curculionids currently are known to be among the most susceptible soil insects to Heterorhabditis nematodes (Poinar and Georgis, 1990). If sensitivity to a volatile signal is as inheritable as demonstrated by studies of Hiltpold et al. (2010), entomopathogenic nematode sensitivity to herbivore induced plant volatiles becomes likely. Future work could evaluate this potential relationship by examining herbivore-induced compounds released by plant roots in sandy coastal regions, along with entomopathogenic nematode bioassays.

\section{Ecological Impacts of Root Exudates}

Different scenarios of root-exuded allomones to benefit overall plant fitness can be envisaged. For example, 1) plants can indirectly benefit from emissions of kairomones that attract bacterial or fungal feeders, which in turn can benefit plants by stimulating microbial community turnover and organic matter recycling (e.g., Luscher et al., 2004; Chapman et al., 2006). 2) Plants can emit molecules that can be defensive towards antagonists, such as the plant-parasitic nematodes (direct defense). For example, the roots of the french marigolds (Tagetes patula and T. erecta) contain $\alpha$-terthienyl and other derivates of bithienyl, both of which can inhibit populations of Meloidogyne and Pratylenchus (Giebel, 1982). Roots of nematode-resistant banana plants were found to contain high levels of flavonoids, dopamine, caffeic esters, and ferrulic acids (Valette et al., 1998). Ferrulic acid molecules bound to cell walls of banana plants then were speculated to reduce the activity of cell wall-degrading enzymes in Radopholus similis nematodes (Wuyts et al., 2007). 3) Exudation of damaged roots can attract entomopathogenic nematodes to their arthropod hosts (indirect defenses). Based on evidence gathered here, different scenarios of root-exuded allomones to benefit overall plant fitness can be envisaged. For example, the common milkweed Asclepias syriaca is generally fed by the specialist root herbivore larvae of the cerambycid beetle Tetraopes tetraophthalmus. Emissions of volatile organic compounds by common milkweed in the soil can increase after insect damage. In lab experiments, this increased emission was correlated with increased entomopathogenic nematodes $H$. bacteriophora attraction. Subsequent field trials demonstrated that soil inoculation of entomopathogenic nematodes benefitted the plants by restoring plant biomass to control levels (Rasmann et al., 2011b). This, with previous work on bush lupine (Strong et al., 1996, 1999), is probably the best evidence of a natural subterranean trophic cascade that may result into enhanced plant performance. Whether or not this is correlated with higher levels of particular volatile emissions has not been assessed. Roots of $A$. syriaca plants emit a very complex mixture of $>30$ compounds of which only few are described as being in the terpene family (Rasmann et al., 2011b). Such a complex blend by itself

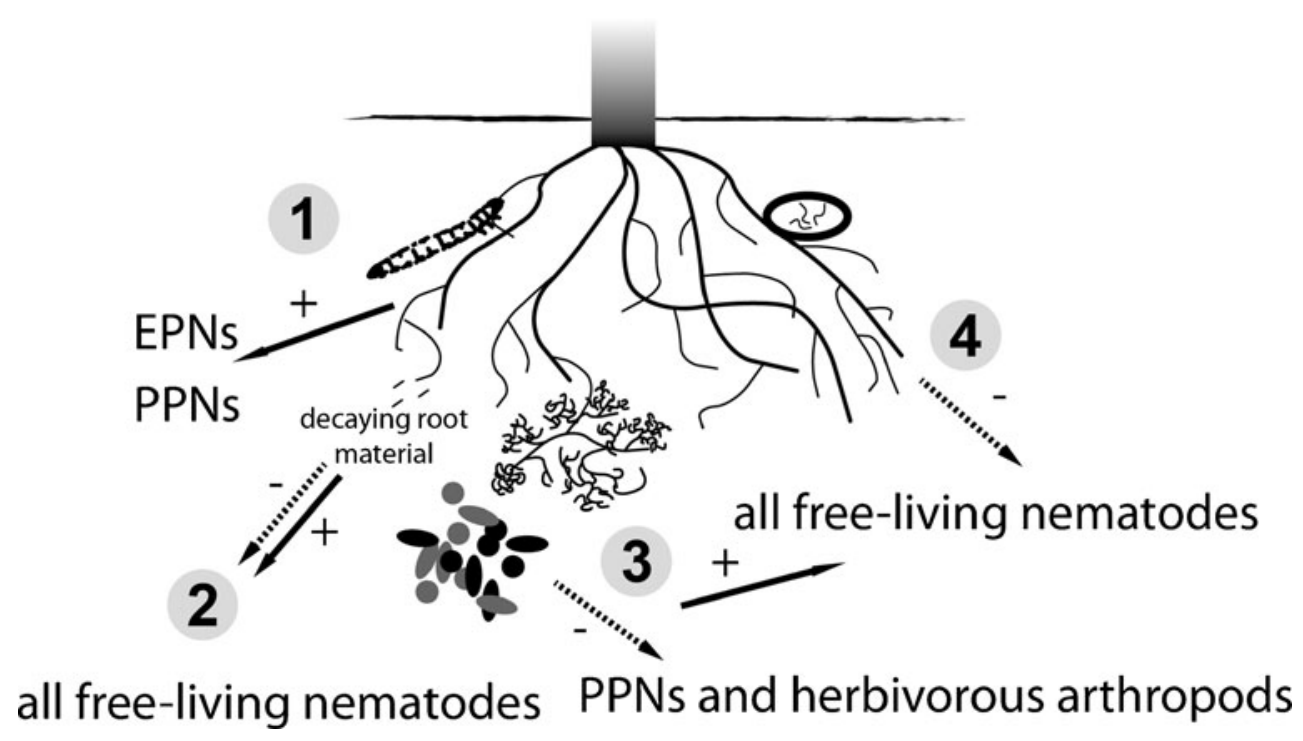

Fig. 2 Belowground plant chemically-derived nematode community structuring. Because of generalized and widespread detection of similar compounds across different nematode groups as shown in Fig. 1, we propose that 1) herbivorous arthropods or plant-parasitic nematodes (PPNs) can induce plants to release chemical organic compounds in the soil matrix, which can attract other herbivores (PPNs) as well as entomopathogenic nematodes (EPNs). 2) Root leachates and rootbased detritus can become information cues for all free living nematodes in the rhizosphere. 3) Root symbiotic fungi and bacteria can stimulate root respiration $\left(\mathrm{CO}_{2}\right)$ and exudation to attract plantparasitic nematodes as well as root-feeding arthropods. Fungi and bacteria not directly associated with roots by living in the rhizosphere can increase $\mathrm{CO}_{2}$ levels to attract free-living soil nematodes. 4) Plants can counteract nematode attack by producing repelling compounds, which can simultaneously repel other free-living nematodes 
already impedes the assessment of which particular compounds are responsible for the attraction. A problem similar to one found in above-ground systems (Hare, 2011), where the emerging picture is that volatile production in plants is the result of diffuse selection due to multiple players interacting with the plant.

The emission of organic molecules can have unintended effects on non-target organisms in addition to nematodes. For example, increased $\mathrm{CO} 2$ levels or other exudates have been shown to attract herbivorous arthropods, which can further decrease plant fitness (see Johnson and Nielsen, 2012, this issue). Therefore, nematode-induced changes in soil chemical characteristics may contribute to the structuring of specific communities around roots. These complex interactions may limit the development of optimal soil management practices. For example, the insect herbivoreinduced emissions of terpenes by citrus plants have been shown to attract entomopathogenic nematodes (Ali et al., 2010; 2011). These compounds also may attract plantparasitic nematodes T. semipenetrans (Ali et al., 2011). Therefore, unless rootstocks are not otherwise resistant to T. semipenetrans, this co-attraction may hamper the exploitation of citrus-induced volatile emission in biological control strategies that target the root weevil Diaprepes abbreviates. In Fig. 2 we have outlined possible directand indirect chemically-mediated effects on different nematode feeding guilds. Undoubtedly, future work is needed to complement the paucity of literature on the exact nature of compounds driving nematode foraging behavior.

\section{Conclusions}

Nematodes from different feeding guilds can 'smell' and 'taste' a variety of diverse compounds in soil. The sensatory capacity of different nematode feeding guilds is remarkably similar, and there appears to be a key role for some general compounds, such as $\mathrm{CO}_{2}$, to be ubiquitous nematode attractants. Plant-borne soil chemical signatures can attract nematodes, thus structuring nematode communities in the rhizosphere. Different nematode species will in turn impose specific selective pressure on plants to produce a unique blend of chemical exudates. Of course, this only plays a role in wild plants that are not under artificial selection by plant breeders. The fitness benefits for plants to produce specific root exudates in soil is then the net outcome of diffuse coevolution imposed by all soil organism in the rhizosphere, including nematodes from all trophic levels (Fig. 2).

The relative simple laboratory settings in which most bioassays described above were done undoubtedly have produced a highly simplified version of the complex chemical profile of natural soils, where thousands of similar molecules co-exist. Interestingly, however, chemical complexity seems to facilitate nematode foraging behavior. A recent report shows that $\mathrm{CO}_{2}$ interacts synergistically with $(E)$-b-caryophyllene and dimethyl disulfide to increase $H$. megidis nematode attraction (Turlings et al., 2012). Future work should, therefore, aim at measuring single but also interactive effects of organic molecules that drive nematode behavior. Chemical characterization of agricultural soils might be a better starting point, not only for applied reasons of improving biological control of crop pests, but also from the fundamental point of view of understanding ecological mechanisms driving nematode foraging behavior. However, complementary studies in natural soils are needed in order to understand evolutionary mechanisms that drive nematode foraging behavior. For example, most of the volatile and non-volatile cues involved in belowground defense and resistance against herbivores remain unknown. Understanding more of these complex mechanisms that drive plant-nematode interactions would not only allow a better understanding of ecological interactions in the rhizosphere, but also offer ecologically sound alternatives in pest management in agricultural systems, such as breeding more attractive plants, intercropping attractive pest-resistant plants, or genetically modify crop plants for increased resistance (see Hiltpold and Turlings, 2012, this issue).

Acknowledgments We thank Larry W. Duncan, Raquel CamposHerrera, Matthias Erb, and an anonymous reviewer for helpful comments. Our research is supported by an Ambizione fellowship from the Swiss National Science Foundation (PZ00P3_131956/1 to SR).

\section{References}

ABou-SetTA, M. M. and DunCAN, L. W. 1998. Attraction of Tylenchulus semipenetrans and Meloidogyne javanica to salts in vitro. Nematropica 28(1):49-59.

Ali, J. G., AlBorn, H. T., CAMPos-Herrera, R., KAPlan, F., DunCAN, L. W., KopPenhofer, A., RodrigueZ-SaOnA, C., and STElinski, L. L. 2012 In press. Subterranean, herbivore-induced plant volatile increases biological control activity of multiple beneficial nematode species in distinct habitats. PLos ONE.

Ali, J., AlBORN, H., and STELINSKI, L. 2010. Subterranean herbivoreinduced volatiles released by Citrus roots upon feeding by Diaprepes abbreviatus recruit entomopathogenic nematodes. $J$. Chem. Ecol. 36(4):361-368.

Ali, J. G., AlboRn, H. T., and Stelinski, L. L. 2011. Constitutive and induced subterranean plant volatiles attract both entomopathogenic and plant parasitic nematodes. J. Ecol. 99(1):26-35.

ANDERson, R. V. and Coleman, D. C. 1981. Population development and interactions between two species of bacteriophagic nematodes. Nematologica 27(1):6-19.

Bais, H. P., Weir, T. L., Perry, L. G., Gilroy, S., and Vivanco, J. M. 2006. The role of root exudates in rhizosphere interations with plants and other organisms. Annu. Rev. Plant Biol. 57:233-266.

BALANOVA, J. and BALAN, J. 1991. Chemotaxis-controlled search for food by the nematode Panagrellus redivivus. Biologia 46:257263.

BAldwin, J. G., NADler, S. A., and AdAms, B. J. 2004. Evolution of plant parasitism among nematodes. Annu. Rev. Phytopathol. 42:83-105. 
Bargmann, C. I. and Horvitz, H. R. 1991. Chemosensory neurons with overlapping functions direct chemotaxis to multiple chemicals in C. elegans. Neuron 7:729-742.

BargmanN, C. I. and Mori, I. 1997. Chemotaxis and thermotaxis, pp. 717-737, in D. L. Riddle, T. Blumenthal, B. J. Meyer, and J. R. Preiss (eds.), C. elegans II, 2nd ed. Cold Spring Harbor Laboratory Press, Cold Spring Harbor (NY).

BEZEMER, T. M. and VAN DAM, N. M. 2005. Linking aboveground and belowground interactions via induced plant defenses. Trends Ecol. Evol. 20(11):617-624.

Bilgrami, A. L. 1997. Nematode biopesticides. Aligarh Muslim University, Aligarh, India. $262 \mathrm{p}$

Bilgrami, A. L., Kondo, E., and Yoshiga, T. 2001a. Absolute and relative preferential attraction of Steinernema glaseri to excretory substances of insects. Int. J. Nematol. 11:27-34.

Bilgrami, A. L., Kondo, E., and Yoshiga, T. 2001b. Attraction response of Steinernema glaseri in presence of plant roots and leaves. Ann. Plant Protect. Sci. 9:258-263.

BIRD, A. F. 1960. Additional notes on the attractiveness of roots to plant parasitic nematodes. Nematologica 5:217.

Blaxter, M. L., De Ley, P., Garey, J. R., LiU, L. X., Scheldeman, P., Vierstraete, A., Vanfleteren, J. R., Mackey, L. Y., DorRIS, M., FRISSE, L. M., ET AL. 1998. A molecular evolutionary framework for the phylum Nematoda. Nature 392(6671):71-75.

BofF, M. I. C., ZoON, F. C., and SMITS, P. H. 2001. Orientation of Heterorhabditis megidis to insect hosts and plant roots in a Y-tube sand olfactometer. Entomol. Exp. Appl. 98(3):329-337.

BofF, M. I. C., VAN TOL, R., and SMITS, P. H. 2002. Behavioural response of Heterorhabditis megidis towards plant roots and insect larvae. Biocontrol 47(1):67-83.

BONKOWSKI, M., VILLENAVE, C., and GRIFFITHS, B. 2009. Rhizosphere fauna: the functional and structural diversity of intimate interactions of soil fauna with plant roots. Plant Soil 321(1-2):213-233.

Buyer, J. S., Roberts, D. P., and Russek-Cohen, E. 2002. Soil and plant effects on microbial community structure. Can. J. Microbiol. 48(11):955-964.

CAmpBell, J. F. and Gaugler, R. 1993. Nictation behaviour and its ecological implications in the host search strategies of entomopathogenic nematodes (Heterorhabditidae and Steinernematidae). Behaviour 126:155-169.

CAMPBELL, J. F. and GAUGLER, R. R. 1997. Inter-specific variation in entomopathogenic nematode foraging strategy: Dichotomy or variation along a continuum? Fundam. Appl. Nematol. 20(4):393-398.

Campbell, J. F., Lewis, E. E., Stock, S. P., NAdler, S., and Kaya, H. K. 2003. Evolution of host search strategies in entomopathogenic nematodes. J. Nematol. 35(2):142-145.

CAstro, C. E., Belser, N. O., MCKinney, H. E., and Thomason, I. J. 1989. Quantitative bioassay for chemotaxis with plant-parasitic nematodes: attractant and repellent fractions for Meloidogyne incognita from cucumber roots. J. Chem. Ecol. 15(4):1297-1309.

Chapman, S. K., Langley, J. A., Hart, S. C., and Koch, G. W. 2006. Plants actively control nitrogen cycling: uncorking the microbial bottleneck. New Phytol. 169(1):27-34.

Chitwood, D. J. 2002. Phytochemical based strategies for nematode control. Annu. Rev. Phytopathol. 40:221-249.

COLEMAN, D. C. 1976. A review or root production processes and their infuence on soil biota in terrestrial ecosystems, pp. 417-434, in J. M. Anderson and A. Macfadyen (eds.), The Role of Terrestrial and Aquatic Organisms in Decomposition Processes. Blackwell Scientific Publications, London.

Coleman, D. C., Crossley, D. A., and Hendrix, P. F. 2004. Fundamentals of Soil Ecology. Elsevier, Burlington, San Diego, London. 386 p.

CURTIS, R. H. C., ROBINSON, A. F., and PERRY, R. N. 2009. Hatch and host location, pp. 139-155, in R. N. Perry, M. Moens, and J. L. Starr (eds.), Root-Knot Nematodes. CAB International, Wallingford, UK and Cambridge, USA.
De Deyn, G. B., RaAijmakers, C. E., Zoomer, H. R., Berg, M. P., DE Ruiter, P. C., VerHoef, H. A., BEZEMER, T. M., and VAN DER PUTTEN, W. H. 2003. Soil invertebrate fauna enhances grassland succession and diversity. Nature 422(6933):711-713.

De Deyn, G. B., RaAijmakers, C. E., and Van der Putten, W. H. 2004. Plant community development is affected by nutrients and soil biota. J. Ecol. 92(5):824-834.

De La Peña, E., RodrigueZ-EcheVerria, S., VAN Der Putten, W. H., Freitas, H., and Moens, M. 2006. Mechanism of control of root-feeding nematodes by mycorrhizal fungi in the dune grass Ammophila arenaria. New Phytol. 169(4):829-840.

De Ruiter, P. C., Moore, J. C., Zwart, K. B., Bouwman, L. A., Hassink, J., Bloem, J., de Vos, J. A., Marinissen, J. C. Y., DidDEN, W. A. M., LebBinK, G., ET AL. 1993. Simulation of nitrogen mineralization in the below-ground food webs of two winter wheat fields. J. Appl. Ecol. 30:95-106.

DEvine, K. J. and JonES, P. W. 2003. Investigations into the chemoattraction of the potato cyst nematodes Globodera rostochiensis and G. pallida towards fractionated potato root leachate. Nematology 5(1):65-75.

Dougherty, E. C. and Nigon, V. 1949. A new species of the freeliving nematode genus Rhabdilis of interest in comparative physiology and genetics. J. Parasitol. 35(suppl):11.

DUSENBERY, D. B. 1980. Responses of the nematode Caenorhabditis elegans to controlled chemical stimulation. J. Comp. Physiol. A Neuroethol. Sens. Neural Behav. Physiol. 136(4):327-331.

DUSENBERY, D. B. 1987. Theoretical range over which bacteria and nematodes locate plant roots using carbon dioxide. J. Chem. Ecol. 13(7):1617-1624.

EDMUNDS, J. E. and MAI, W. F. 1967. Effects of Fusarium oxysporum on movement of Pratylenchus penetrans towards alfalfa roots. Phytopathology 57:468-471.

ENNIS, D. E., DILlON, A. B., and GRIFFIN, C. T. 2010. Simulated roots and host feeding enhance infection of subterranean insects by the entomopathogenic nematode Steinernema carpocapsae. J. Invert. Pathol. 103(2):140-143.

Erb, M., Ton, J., Degenhardt, J., and Turlings, T. C. J. 2008. Interactions between arthropod-induced aboveground and belowground defenses in plants. Plant Physiol. 146(3):867-874.

FogEL, R. 1985. Roots as primary producers in below-ground ecosystems, pp. 23-36, in A. H. Fitter, D. Atkinson, D. J. Read, and M. B. Usher (eds.), Ecological Interactions in Soil: Plants, Microbes, and Animals. Blackwell, Oxford.

FrANCO, J., MAIN, G., and OROS, R. 1999. Trap crops as a component for the integrated management of Globodera spp. (potato cyst nematodes) in Bolivia. Nematropica 29:51-60.

Fu, S., Ferris, H., Brown, D., and Plant, R. 2005. Does the positive feedback effect of nematodes on the biomass and activity of their bacteria prey vary with nematode species and population size? Soil Biol. Biochem. 37:1979-1987.

GANGe, A. C. and Brown, V. K. 2002. Multitrophic Interactions in Terrestrial Systems. Cambridge University Press, Cambridge, UK.

Gaugler, R. (ED.) 2002. Entomopathogenic Nematology. CABI, New York, USA.

Gaugler, R. and BiLgrami, A. L. (eds.) 2004. Nematode Behaviour. CABI, New York, USA.

GAUGLER, R. and KAYA, H. K. 1990. Entomopathogenic Nematodes in Biological Control. CRC Press, Boca Raton, Florida, USA.

GIEBEL, J. 1982. Mechanism of resistance to plant nematodes. Annu. Rev. Phytopathol. 20:257-279.

Goode, M. and DusenBery, D. B. 1985. Behavior of tethered Meloidogyne incognita. J. Nematol. 17(4):460-464.

Grewal, P. S., LEWIS, E. E., GAUGLER, R., and CAMPBell, J. F. 1994. Host finding behavior as a predictor of foraging strategy in entomopathogenic nematodes. Parasitology 108:207215 . 
Hallem, E. A., Dillman, A. R., Hong, A. V., Zhang, Y. J., Yano, J. M., Demarco, S. F., and SternberG, P. W. 2011. A sensory code for host seeking in parasitic nematodes. Curr. Biol. 21(5):377-383.

Hara, A. H., Gaugler, R., Kaya, H. K., and LebecK, L. M. 1991. Natural populations of entomopathogenic nematodes (Rhabditida, Heterorhabditidae, Steinernematidae) from the Hawaiian islands. Environ. Entomol. 20(1):211-216.

HARE, J. D. 2011. Ecological role of volatiles produced by plants in response to damage by herbivorous insects. Annu. Rev. Entomol. 56:161-180.

HARVEY, E. N. 1952. Bioluminescence. Academic, New York.

Hedlund, K., Griffiths, B., Christensen, S., Scheu, S., Setälä, H., TscharntKe, T., and Verhoef, H. 2004. Trophic interactions in changing landscapes: responses of soil food webs. Basic Appl. Ecol. 5(6):495-503.

Hilliard, M. A., Bargmann, C. I., and Bazzicalupo, P. 2002. $C$. elegans responds to chemical repellents by integrating sensory inputs from the head and the tail. Curr. Biol. 12(9):730-734.

HiltPold, I., BARONI, M., TOEPFER, S., KuHLMANN, U., and TuRLings, T. C. J. 2010. Selection of entomopathogenic nematodes for enhanced responsiveness to a volatile root signal helps to control a major root pest. J. Exp. Biol. 213(14):2417-2423.

Holterman, M., van Der WurfF, A., van den Elsen, S., van Megen, H., Bongers, T., Holovachov, O., BaKker, J., and HELDER, J. 2006. Phylum-wide analysis of SSU rDNA reveals deep phylogenetic relationships among nematodes and accelerated evolution toward crown clades. Mol. Biol. Evol. 23(9):1792-1800.

Huang, X., Huang, P., Robinson, M. K., Stern, M. J., and Jin, Y. 2003. UNC-71, a disintegrin and metalloprotease (ADAM) protein, regulates motor axon guidance and sex myoblast migration in C. elegans. Development 130(14)):3147-3161.

HunTER, M. D. 2001. Out of sight, out of mind: the impacts of rootfeeding insects in natural and MANAGED SYSTEMS. AGRIC. FOR. ENTOMOL. 3(1):3-9.

Ingham, R. E., Trofymow, J. A., Ingham, E. R., and Coleman, D. C. 1985. Interactions of bacteria, fungi and their nematode grazers on nutrient cycling and plant growth. Ecol. Monogr. 55:119-140.

ISHIBASHI, N. and KONDO, E. 1990. Behavior of infective juveniles, in R. Gaugler and H. K. Kaya (eds.), Entomopathogenic Nematodes in Biological Control. CRC, Boca Raton.

Johnson, S. N. and GREGORY, P. J. 2006. Chemically-mediated hostplant location and selection by root-feeding insects. Physiol. Entomol. 31(1):1-13.

JONES, J. 2002. Nematode sense organs, pp. 369-387, in D. L. Lee (ed.), The Biology of Nematodes. Taylor \& Francis Inc, New York, NY, USA.

KAPlAN, I., HALITSCHKE, R., KeSSLER, A., SARDANELli, S., and DENNO, R. F. 2008. Constitutive and induced defenses to herbivory in above- and belowground plant tissues. Ecology 89(2):392-406.

KARBAN, R. and BALDWIN, I. 1997. Induced Responses to Herbivory. University Press of Chicago, Chicago.

KAYA, H. K. and GAUGLER, R. 1993. Entomopathogenic nematodes. Annu. Rev. Entomol. 38:181-206.

KLINGER, J. 1963. Die Orientierung von Ditylenchus dipsaci in gemessen kunstlichen und biologischen $\mathrm{CO}_{2}$ Gradienten. Nematologica 9:185-199.

KLINGER, J. 1970. The reaction of Aphelenchoides fragrariae to slitlike micro-openings and TO STOMATAL DIFFUSION GASES. NEMATOLOGICA 16:417-422.

KLINK, J. W. 1969. Studies on the host finding mechanisms of Neotylenchus linfordi. J. Nematol. 2:106-117.

Kollner, T. G., Held, M., LenK, C., Hiltpold, I., Turlings, T. C. J., GERShENZON, J., and Degenhardt, J. 2008. A maize (E)-betacaryophyllene synthase implicated in indirect defense responses against herbivores is not expressed in most American maize varieties. Plant Cell 20(2):482-494.
LEE, D. L. 2002. Behaviour, pp. 369-387, in D. L. Lee (ed.), The Biology of Nematodes. Taylor \& Francis Inc., New York, NY, USA.

LEWIS, E. E., GAUGLER, R., and HARRISON, R. 1992. Entomopathogenic nematode host finding - Response to host contact cues by cruise and ambush foragers. Parasitology 105:309-315.

Lewis, E. E., GAUGler, R., and Harrison, R. 1993. Response of cruiser and ambusher entomopathogenic nematodes (Steinernematidae) to host volatile cues. Can. J. Zool.-Rev. Can. Zool. 71 (4):765-769.

Luscher, A., Daepr, M., Blum, H., Hartwig, U. A., and NosBERGER, J. 2004. Fertile temperate grassland under elevated atmospheric $\mathrm{CO} 2$ - role of feed-back mechanisms and availability of growth resources. Eur. J. Agron. 21(3):379-398.

Masamune, T., Anetai, M., TaKasugi, M., and Katsui, N. 1982. Isolation of a natural hatching stimulus, glycinoeclepin $\mathrm{A}$, for the soybean cyst nematode. Nature 297(5866):495-496.

McCallum, M. E. and Dusenbery, D. B. 1992. Computer tracking as a behavioral GC detector: Nematode responses to vapor of host roots. J. Chem. Ecol. 18(4):585-592.

Moens, T., Verbeeck, L., De Maeyer, A., Swings, J., and VincX, M. 1999. Selective attraction of marine bacterivorous nematodes to their bacterial food. Mar. Ecol. Prog. Ser. 176:165-178.

Mortimer, S. R., Putten, W. H. V. D., and Brown, V. K. 1999. Insect and nematode herbivory below ground: interactions and role in vegetation succession, pp. 205-238, in H. Olff, V. K. Brown, and R. H. Drent (eds.), HERBIVORES: Between Plants and Predators. Blackwell Science Ltd., Oxford.

Bert, W., Karssen, G., and Helder J. 2011. Phylogeny and evolution of nematodes, pp 45-60, in J Jones, G Gheysen, C Fenoll (eds), Genomics and Molecular Genetics of Plant-Nematode Interactions. Springer Science+Business Media B.V.

ERB M., GLAUSER G., and RoBERT C.A.M. 2012. Induced immunity against belowground insect herbivores-activation of defenses in the absence of a jasmonate burst. J. Chem. Ecol. 38(6):this issue.

HiLTPOLD, I., and TURLINGS, T.C.J. 2012. Manipulation of chemically mediated interactions in agricultural soils to enhance the control of crop pests. J. Chem. Ecol. 38(6): this issue.

JOHNSON, S.N., AND NIELSEN, U.N. 2012. Foraging in the darkChemically mediated host plant location by belowground insect herbivores. J. Chem. Ecol. 38(6): this issue.

LEWIS E.E. 2002. Behavioural ecology, pp 205-223, in R Gaugler (ed.), Entomopathogenic Nematology. CAB International.

Sengupta P., Colbert H.A., Kimmel B.E., Dwyer N., BargmanN C.I. 1993. The cellular and genetic basis of olfactory responses in Caenorhabditis elegans, pp. 235-250. Ciba Foundation Symposia.

TURLINGS T.C.J., HiLtPOLD I., RASMANN S. 2012. The importance of root-produced volatiles as foraging cues for entomopathogenic nematodes. Plant Soil in press.

O'Halloran, D. M. and BURNELl, A. M. 2003. An investigation of chemotaxis in the insect parasitic nematode Heterorhabditis bacteriophora. Parasitology 127:375-385.

PERRY, R. N. 1997. Plant signals in nematode hatching and attraction, pp. 38-50, in C. Fenoll, F. M. W. Grundler, and S. A. Ohl (eds.), Cellular and Molecular Aspects of Plant-Nematode Interactions. Kluwer Academic Press, Dordrecht, The Netherlands.

PERRY, R. N. and AUMANN, J. 1998. Behaviour and sensory responses, pp. 75-102, in R. N. Perry and D. J. Wright (eds.), The Physiology and Biochemistry of Free-living and Plant-parasitic Nematodes. CAB International Press, Wallingford, UK.

Perry, R. N. and Wesemael, W. M. L. 2008. Host plant effects on hatching of root-knot nematodes. Russ. J. Nemat. 16(1):1-5.

Perry, R. N., MoEnS, M., and StARr, J. L. 2009. Root-knot Nematodes. CAB International, Wallingford, UK and Cambridge, USA. 488 p.

Pline, M. and DusenBery, D. B. 1987. Responses of plant-parasitic nematode Meloidogyne incognita to carbon dioxide determined by video camera-computer tracking. J. Chem. Ecol. 13(4):873-888. 
PoINAR, G. O. 1990. Taxonomy and Biology of Steneirnematidae and Herorhabditidae, in R. Gaugler and H. K. Kaya (eds.), Entomopathogenic Nematodes in Biological Control. CRC, Boca Raton.

POINAR, G. O. 1993. Origins and phylogentic relationships of the entomophilic rhabditids, Heterorhabditis and Steinnernema. Fundam. Appl. Nematol. 16:333-338.

PoINAR, G. O. and GeORGIS, R. 1990. Description and field application of the HP88 strain of Heterorhabditis bacteriophora. Rev. Nématol. 13:387-393.

Price, P. W., Bouton, C. E., Gross, P., McPheron, B. A., ThompSON, J. N., and WEIS, A. E. 1980. Interactions among three trophic levels: influence of plant on interactions between insect herbivores and natural enemies. Annu. Rev. Ecol. Syst. 11:41-65.

PROT, J. C. 1980. Migration of plant-parasitic nematodes towards plant roots. Rev. Nématol. 7:374-379.

RAsmann, S. and Agrawal, A. A. 2008. In defense of roots: A research agenda for studying plant resistance to belowground herbivory. Plant Physiol. 146(3):875-880.

RASMANN, S. and TURLINGS, T. C. J. 2008. First insights into specificity of belowground tritrophic interactions. Oikos 117(3):362-369.

Rasmann, S., Kollner, T. G., Degenhardt, J., Hiltpold, I., ToePFER, S., Kuhlmann, U., Gershenzon, J., and TurlingS, T. C. J. 2005. Recruitment of entomopathogenic nematodes by insectdamaged maize roots. Nature 434(7034):732-737.

Rasmann, S., Bauerle, T. L., Poveda, K., and Vannette, R. 2011a. Predicting root defence against herbivores during succession. Funct. Ecol. 25(2):368-379.

Rasmann, S., Erwin, A. C., Halitschke, R., and Agrawal, A. A. 2011b. Direct and indirect root defences of milkweed (Asclepias syriaca): trophic cascades, trade-offs and novel methods for studying subterranean herbivory. J. Ecol. 99(1):16-25.

ReIneCKe, A., Muller, F., and HilKer, M. 2008. Attractiveness of $\mathrm{CO}(2)$ released by root respiration fades on the background of root exudates. Basic Appl. Ecol. 9(5):568-576.

RIDDLE, D. L. and BIRD, A. F. 1985. Responses of the plant parasitic nematodes Rotylenchulus reniformis, Anguina agrostis and Meloidogyne javanica to chemical attractants. Parasitology 91 (01):185-195.

RIGA, E. 2004. Orientation behaviour, pp. 63-90, in R. Gaugler and A. L. Bilgrami (eds.), Nematode Behaviour. CAB International Press, Wallingford, UK and Cambridge, USA.

RoBINSON, A. F. 1995. Optimal release rates for attracting Meloidogyne incognita by alginate pellets containing hyphae of Monacrosporium cionopagum, M. ellipsosporum, or Hirsutella rhossiliensis. J. Nematol. 28:133-147.

Rolfe, R. N., BArrett, J., and Perry, R. N. 2000. Analysis of chemosensory responses of second stage juveniles of Globodera rostochiensis using electrophysiological techniques. Nematology 2(5):523-533.

Schenk, H., Driessen, R. A. J., De Gelder, R., Goubitz, K., NieBOER, H., BRUgGemanN-Rotgans, I. E. M., and DiEPENHORST, P. 1999. Elucidation of the structure of Solanoeclepin A, a natural hatching factor of potato and tomato cyst nematodes, by singlecrystal x-ray diffraction. Croat Chem Acta 72(2-3):593-606.

Schoonhoven, L. M., van LoOn, J. J. A., and Dicke, M. 2005. Insect-plant Biology. Oxford University Press, Oxford.

Strong, D. R., KaYA, H. K., Whipple, A. V., Child, A. L., Kraig, S., BondonNo, M., DYER, K., and MARON, J. L. 1996. Entomopathogenic nematodes: natural enemies of root-feeding caterpillars on bush lupine. Oecologia 108(1):167-173.

Strong, D. R., Whipple, A. V., Child, A. L., and DenNis, B. 1999. Model selection for a subterranean trophic cascade: root-feeding caterpillars and entomopathogenic nematodes. Ecology 80 (8):2750-2761.

Tietjen, J. H., Lee, J. J., Rullman, J., Greengart, A., and Trompeter, J. 1970. Gnotobiotic culture and physiological ecology of the marine nematode, Rhabditis marina. Bastian. Limnol. Oceanogr. 15:535-543.

TscharntKe, T. and HawkINS, B. A. 2002. Multitrophic Level Interactions. Cambridge University Press, Cambridge, UK.

Valette, C., ANDARY, C., Geiger, J. P., SARah, J. L., and Nicole, M. 1998. Histochemical and cytochemical investigations of phenols in roots of banana infected by the burrowing nematode Radopholus similis. Phytopathology 88(11):1141-1148.

VAN DAM, N. M. 2009. Belowground herbivory and plant defenses. Annu. Rev. Ecol. Evol. Syst. 40:373-391.

VAN der PUtTEN, W. H. 2003. Plant defense belowground and spatiotemporal processes in natural vegetation. Ecology 84(9):2269-2280.

VAN DER Putten, W. H., Vet, L. E. M., HARVEy, J. A., and Wackers, F. L. 2001. Linking above- and belowground multitrophic interactions of plants, herbivores, pathogens, and their antagonists. Trends Ecol. Evol. 16(10):547-554.

Van der Putten, W. H., Bardgett, R. D., de Ruiter, P. C., Hol, W. H. G., Meyer, K. M., Bezemer, T. M., Bradford, M. A., Christensen, S., Eppinga, M. B., Fukami, T., et al. 2009. Empirical and theoretical challenges in abovegroundbelowground ecology. Oecologia 161(1):1-14.

van TOl, R., van der SOMmen, A. T. C., BOFF, M. I. C., van Bezooijen, J., SABelis, M. W., and Smits, P. H. 2001. Plants protect their roots by alerting the enemies of grubs. Ecol. Lett. 4 (4):292-294.

VET, L. E. M. and DicKE, M. 1992. Ecology of infochemical use by natural enemies in a tritrophic context. Annu. Rev. Entomol. 37:141-172.

Viglierchio, D. R. 1990. Carbon dioxide sensing by Panagrellus silusiae and Ditylenchus dipsaci. Rev. Nématol. 13:425-432.

Viketoft, M., Bengtsson, J., Sohlenius, B., Berg, M. P., Petchey, O., Palmborg, C., and Huss-Danell, K. 2009. Long-term effects of plant diversity and composition on soil nematode communities in model grasslands. Ecology 90(1):90-99.

VON LENGERKEN H. 1929. The salt beetle of the North- and East sea coast with consideration of the neighbouring seas and the Mediterranean, the Black and the Caspian Sea - An ecological biological geographical study. Zeitschrift Fur Wissenschaftliche Zoologie 135(1/2):1-162.

WalKer, T. S., Bais, H. P., Grotewold, E., and VivanCo, J. M. 2003. Root exudation and rhizosphere biology. Plant Physiol. 132(1):44-51.

WANG, C. L., BRUENING, G., and Williamson, V. M. 2009. Determination of preferred $\mathrm{pH}$ for root-knot nematode aggregation using Pluronic F-127 Gel. J. Chem. Ecol. 35(10):1242-1251.

WARD, S. 1978. Nematode chemotaxis and chemoreceptors, pp. 143-168, in G. L. Hazelbauer (ed.), Taxis and Behavior (Receptors and Recognition). Chapman and Hall, London.

Wardle, D. A. 2002. Communities and Ecosystems: Linking the Aboveground and Belowgroound Components. Princeton University Press, Princeton, NJ.

WhitTAKeR, J. B. 2003. Root-animal interaction, pp. 363-385, in H. de Kroon and E. J. W. Wisser (eds.), Root Ecology. Springer, Berlin Heidelberg New York.

Wuyts, N., Lognay, G., Verscheure, M., Marlier, M., De Waele, D., and SwenNEN, R. 2007. Potential physical and chemical barriers to infection by the burrowing nematode Radopholus similis in roots of susceptible and resistant banana (Musa spp.). Plant Pathol. 56(5):878-890.

WYSS, U. 2002. Feeding behaviour of plant-parasitic nematodes, pp. 369-387, in D. L. Lee (ed.), The Biology of Nematodes. Taylor \& Francis Inc., New York, NY, USA.

YeATES, G. W. 1999. Effects of plants on nematode community structure. Annu. Rev. Phytopathol. 37(1):127-149.

Yeates, G. W., Ferris, H., Moens, T., and Van Der Putten, W. H. 2009. Role of nematodes in ecosystems, pp. 1-44, in M. J. Wilson and T. Kakouli-Duarte (eds.), Nematodes as Environmental Indicators. CAB International, Walingford, UK. 